\title{
ANALISIS TOKOH DAN PENOKOHAN DALAM NOVEL KEAJAIBAN ADAM KARYA GUSTI M FABIANO TAHUN 2019
}

\author{
Ainun Mardhiah ${ }^{1}$, Joko Hariadi, Prima Nucifera \\ ${ }^{I}$ Mahasiswa Program Studi Bahasa Indonesia, FKIP Universitas Samudra \\ ${ }^{1}$ ainun992015@gmail.com
}

Info Artikel :

Diterima:

Disetujui:

Dipublikasikan:
Abstract

This study aims to describe the characters and characterizations in the Adam Miracle novel by Gusti M Fabiano. The method used in this research uses desciptve analiytic method. The source of the data was obtained from the Adam Miracle novel related to characters dan charaterizations. In this study, researchers used the method of documentation in data collection. The results of the analysis that have been obtained in the Adam Miracle novel Gusti M Fabiano shows that the author gave rise to the twenty-three indentity of the caracters in the Adam Miracle novel Guti M Fabiano. There are saveral figures who are categorized more than one role. The characters in this novel are described through the characters of each character and are described in two techniques, namely expository and dramatic techniques.

Keywords: Analysis, Figures, Characterizations, Adam's Miracle Novels, Gusti M Fabiano

Abstrak

Penelitian ini bertujuan untuk mendeskripsikan tokoh dan penokohan dalam novel Keajaiban Adam karya Gusti M Fabiano. Metode yang digunakan dalam penelitian ini menggunakan metode deskriptif analitik. Sumber data diperoleh dari novel Keajaiban Adam yang berkaitan dengan tokoh dan penokohan. Pada penelitian ini, peneliti menggunakan metode dokumentasi dalam pengumpulan data. Hasil analisis yang telah didapatkan dalam novel Keajaiban Adam karya Gusti M Fabiano menunjukkan bahwa pengarang memunculkan dua puluh tiga identitas tokoh dalam novel Keajaiban Adam karya Gusti M Fabiano. Ada beberapa tokoh yang dikategorikan lebih dari satu perannya. Penokohan dalam novel ini dideskripsikan melalui watak setiap tokoh dan digambarkan dalam dua teknik, yaitu teknik ekspositori dan teknik dramatik. Penulis berharap kepada pengarang novel Gusti M Fabiano untuk menampilkan tokoh pada novel dengan penokohan yang lebih menarik lagi, khususnya pada tokoh utama novel. Tokoh Adam dalam novel Keajaiban Adam terkesan begitu sempurna tanpa adanya karakter negatif sedikitpun dan hal ini sulit dijumpai pada karakter manusia pada umumnya.

Kata kunci: Analisis, Tokoh, Penokohan, Novel Keajaiban Adam, Gusti M Fabiano 


\section{Pendahuluan}

Sastra merupakan sebuah karya yang mengacu pada kreativitas yang bersifat imajinatif. Sastra adalah kreativitas penulis dalam mengungkapkan perasaannya dengan cara meluapkan emosi-emosi tertentu dalam setiap karyanya. Sastra mampu membangkitkan rasa senang, sedih, marah, kecewa dan menjadi hiburan bagi pembaca maupun penulisnya. Karya sastra yang baik adalah karya sastra yang menggunakan bahasa yang disusun secara apik sesuai dengan makna yang akan disampaikan. Sifat dari karya sastra ialah imajinatif. Meskipun karya sastra bersifat imajinatif, cerita-cerita didalamnya menyuguhkan beberapa konflik yang sangat menarik. Konflik yang disuguhkan biasanya tidak terlepas dari masalah-masalah kehidupan seharihari, yakni masalah kemanusiaan.

Karya sastra terbagi menjadi dua yaitu, karya sastra nonfiksi dan fiksi. Karya sastra nonfiksi merupakan karya sastra yang ditulis berdasarkan kajian keilmuan dan pengalaman, sedangkan karya fiksi merupakan cerita rekaan, seperti roman, drama, dan novel. Menurut Nurgiyantoro (2013:12), menjelaskan bahwa "Sebuah cerita yang panjang, katakanlah berjumlah ratusan halaman, jelas tidak disebut sebagai cerpen, melainkan lebih tepat sebagai novel". Novel tidak seperti karya sastra lainnya, seperti cerpen contohnya, novel jauh lebih panjang alur ceritanya dan terkadang terdapat pesan tersembunyi yang ingin disampaikan si penulis kepada pembacanya. Novel menceritakan tentang peristiwa yang berkaitan dengan tokoh-tokoh dan perilaku mereka dalam kehidupan sehari-hari.

Salah satu unsur terpenting dalam novel adalah tokoh dan penokohan. Dalam sebuah novel, tokoh memainkan peranan yang penting dalam alur cerita, sedangkan penokohan adalah pelukisan gambaran yang jelas tentang seseorang yang ditampilkan dalam sebuah cerita. Sebagaimana yang dikemukakan oleh Nurgiyantoro (2013:247), bahwasannya "Istilah tokoh menunjuk kepada orangnya, pelaku cerita. Misalnya sebagai jawaban terhadap pertanyaan "Siapakah tokoh utama novel itu?" atau "ada berapa orang jumlah tokoh novel itu?", dan sebagainya". Tokoh adalah pelaku dalam sebuah cerita, jika tidak ada tokoh berarti tidak ada yang akan diceritakan dan itu bukan sebuah cerita fiksi. Menurut Kemal (2014:68), "Tokoh dalam cerita sama seperti halnya manusia dalam kehidupan sehari-hari dalam kehidupan kita, selalu memiliki watak-watak tertentu". Dalam sebuah novel pembaca selalu yang akan pertama kali ditanyakan adalah siapa tokoh tersebut dan bagaimana wataknya dan baru disertai dengan pertanyaan yang lain-lainya. Tokoh dikelompokkan menjadi sepuluh jenis tokoh.

1. Tokoh utama merupakan tokoh penting dan kemunculannya mendominasi sebagian besar cerita (Seanal, 2016). Menurut Wahyuningtyas dan santosa (2011:3), "Tokoh utama adalah tokoh yang diutamakan penceritaannya dalam prosa yang bersangkutan, ia merupakan tokoh yang paling banyak diceritakan, baik dari segi pelaku kejadian maupun yang dikenai kejadian itu sendiri"

2. Tokoh tambahan biasanya diabaikan kerana sinopsis hanya berisi intisari cerita. Menurut Aminuddin (2015:79), "Tokoh tambahan adalah tokoh yang memiliki peranan tidak penting karena kemunculannya hanya melengkapi, melayani dan mendukung tokoh utama".

3. Tokoh protagonis adalah tokoh yang memiliki watak yang baik sehingga disenangi oleh pembaca (Aminuddin, 2015:80).

4. Tokoh yang menyebabkan konflik dalam sebuah cerita disebut tokoh antagonis. Menurut Wahyuningtyas dan Santosa (2011:4), "Tokoh antagonis adalah tokoh penentang dari tokoh protagonis sehingga menyebabkan konflik dan ketegangan".

5. Menurut Aminuddin (2015:82), “Tokoh sederhana adalah tokoh yang tidak banyak menunjukkan adanya kompleksitas masalah". Tokoh sederhana adalah tokoh yang hanya memiliki satu kualitas pribadi tertentu, satu sifat watak tertentu saja (Nurgiyantoro, 2013:265).

6. Menurut Priyatni (2012:111), "Tokoh bulat adalah tokoh yang banyak dibebani masalah". Tokoh bulat adalah tokoh yang permunculannya banyak dibebani permasalahan.

7. Tokoh statis adalah tokoh yang wataknya tidak mengalami perubahan mulai dari awal cerita hingga akhir cerita (Priyatni, 2012:110). Sependapat dengan Priyatni, Yoanita (2011:780), "Tokoh statis ialah tokoh yang dari awal sampai akhir tidak mengalami perubahan dalam aspek penokohan".

8. Menurut Nurgiyantoro (2013:272), “Tokoh berkembang adalah tokoh cerita yang mengalami perubahan dan berkembang perwatakan sejalan dengan perkembangan (dan perubahan) peristiwa dan plot dikisahkan".

9. Menurut Altenbernd dan Lewis (dalam Nurgiyantoro, 2013:274), "Tokoh tipikal adalah tokoh yang hanya sedikit ditampilkan keadaan individualitasnya dan lebih banyak ditonjolkan kualitas pekerjaan atau kebangsaannya atau sesuatu yang lain yang lebih bersifat mewakili".

10. Kehadirannya tidak berpotensi untuk mewakili atau menggambarkan sesuatu yang diluar dirinya, seseorang yang berasal dari dunia nyata (Nurgiyantoro, 2013:275).

Selanjutnya penokohan, dalam sebuah cerita fiksi penokohan memainkan peranan penting dikarenakan penokohan adalah pelukisan kedirian seorang tokoh. Menurut Fanani (2016:78), "Penokohan adalah penggambaran tokoh dengan 


\section{Volume 3 Nomor 1}

\section{Juni 2020}

berbagai cara agar tokoh tersebut tampak hidup dan berbuat sesuatu". Penokohan ialah cara pengarang menggambarkan karakter tokoh-tokoh dalam cerita (Madina, 2018:36). Penokohan merupakan pemberian karakter atau watak pada seorang tokoh. Pemberian watak atau karakter ini penting dikarenakan dengan memberikan watak atau karakter pembaca bisa mengetahui bagaimana tokoh tersebut digambarkan oleh pengarang. Penokohan adalah pelukisan atau gambaran yang jelas tentang seorang tokoh dalam cerita agar pembaca bisa menafsirkannya dengan jelas. Dengan penokohan pengarang dan pembaca bisa membedakan setiap tokoh yang ada, dikarenakan setiap tokoh digambarkan berbeda-beda dalam karya fiksi. Maka dari itu setiap novel akan menggunakan teknik penokohan yaitu Teknik Ekspositori dan Teknik Dramatik agar novel tersebut menarik untuk dibaca.

Teknik ekspositori yang sering juga disebut sebagai teknik analitis, pelukisan tokoh cerita dilakukan dengan memberikan deskripsi, uraian atau penjelasan secara langsung (Nurgiyantoro, 2013:280). Menurut Minderop (2013:4), "Metode telling mencakup karakterisasi melalui penggunaan nama tokoh, karakterisasi melalui penampilan tokoh, karakterisasi melalui tuturan pengarang". Tidak berbeda dengan Minderop, Pickering dan Hoeper (dalam Minderop, 2013:6), "Metode telling mengandalkan pemaparan watak tokoh pada eksposisi dan komentar langsung dari pengarang".

Sedangkan teknik dramatik ialah teknik yang melibatkan para tokoh. Metode dramatik adalah suatu metode penokohan dengan cara memaparkannya secara tidak langsung (Masruroh, 2017:17). Sedangkan menurut Minderop (2013:22), “.... dengan metode dramatik yang mengabaikan kehadiran pengarang, sehingga para tokoh dalam karya sastra dapat menampilkan diri secara langsung melalui tingkah laku mereka”.

Peneliti tertarik untuk meneliti bagaimana tokoh dan penokohan dalam novel Keajaiban Adam. Analisis tokoh dan penokohan dalam novel Keajaiban Adam menurut penulis belum ada yang melakukannya. Dalam novel Keajaiban Adam, penokohan dan watak setiap tokoh membuat peneliti tertarik untuk menganalisisnya, penulis sangat apik dalam mengambarkan karakter setiap tokoh dan watak di dalam novel Keajaiban Adam. Cerita yang disuguhkan menurut peneliti cukup menarik untuk diteliti, dikarenakan tokoh utama yang bisa melakukan Israj-Miraj dari Masjid Baiturrahman ke Masjidil Haram dalam satu malam dan masih banyak lagi keajaiban tokoh utama. Hal tersebutlah yang mendorong rasa ingin tahu peneliti untuk menganalisisnya.

Tokoh utama dalam novel Keajaiban Adam sangat penyabar dalam menghadapi masalah yang bermunculan, Adam pantang menyerah dalam menghadapi masalah-masalah yang datang menghampirinya. Padahal masalah yang Adam hadapi cukup sulit untuk dihadapi, dikarenakan ada sekelompok orang yang ingin membunuhnya, mereka menganggap Adam pendusta agama dan sesat. Kelompok tersebut mendegar bahwa Adam melakukan Isra-Miraj dari masjid Baiturrahman ke Masjidil Haram. Mereka tidak percaya akan kabar tersebut dan menuduh Adam sesat. Meskipun banyak bukti yang membenarkan hal tersebut, kelompok itu tidak menggubrisnya sama sekali. Mereka menggatakan bahwa halal membunuh Adam bagi mereka yang berjihad di jalan Allah. Hal tersebut terlihat dari kutipan novel tersebut

"....mendengar ucapan salah satu pemuka agama di layar lebar itu, tokoh tersebut dari kalangan Islam radikal dengan memberi pernyataan bahwa: darah Adam halal!!! Peristiwa yang terjadi pada anak muda itu harus ditolak!! Ini merusak aqidah dan mencemarkan mukjizat IsrajMiraj nabi besar Muhammad Saw yang sudah mapan, maka dari Adam bebas bagi siapa saja kaum muslimin untuk membunuhnya!!!" (Fabiano, 204).

Dengan demikian, menurut penulis penelitian ini sangat menarik untuk dikaji sehingga penelitian ini berjudul Analisis Tokoh dan Penokohan dalam Novel Keajaiban Adam Karya Gusti M Fabiano. Peneliti akan menganalisis setiap tokoh yang ada pada novel tersebut

\section{Metode Penelitian}

Pendekatan penelitian yang digunakan dalam penelitian ini adalah pendekatan struktural dengan jenis penelitian deskriptif analitik. Menurut Semi (2012:67), "Pendekatan ini juga sering dinamakan dengan pendekatan objektif, pendekatan formal, atau pendekatan analitik". Strukturaslisme dapat dipandang sebagai salah satu pendekatan kesastraan yang menekan pada kajian hubungan antar unsur pembangun karya sasrta yang bersangkutan (Riani, 2016:148). Sependapat dengan Riani, Teeuw (2015:106), menyatakan bahwa "Analisisis struktural bertujuan untuk membongkar dan memaparkan secermat, seteliti, semendetail, dan semendalam mungkin keterkaitan dan keterjalinan semua anasir dan aspek karya sastra yang bersama-sama menghasilkan makna yang menyeluruh".

Jenis penelitian yang digunakan dalam penelitian ini adalah metode deskriptif analitik. Menurut Ratna (2017:53), "Metode deskriptif analitik dilakukan dengan cara mendeskripsikan fakta-fakta yang kemudian disusul analisis". Dengan menggunakan metode deskriptif analitik peneliti harus menguraikan fakta-fakta yang mendukung dalam analisis tokoh dan penokohan, fakta-fakta tersebut diambil dari novel Keajaiban Adam. Peneliti tidak hanya menguraikan, tetapi harus memahami dalam menganalisis tokoh dan 


\section{Volume 3 Nomor 1}

\section{Juni 2020}

penokohan. Penggunaan metode ini bertujuan untuk mendeskripsikan dan menganalisis data mengenai tokoh dan penokohan dalam novel Keajaiban Adam karya Gusti M Fabiano.

Menurut Arikunto (2006:129), yang dimaksud dengan "Sumber data dalam penelitian adalah subjek dari mana data dapat diperoleh, sumber data disebut dengan responden, yaitu orang yang mengrespon atau menjawab pertanyaanpertanyaan peneliti, baik pertanyaan tertulis atau lisan". Sumber data dalam penelitian ini diperoleh darinovel Keajaiban Adamkarya Gusti M Fabiano yang diterbitkan oleh Yayasan PeNA Banda Aceh pada Agustus 2012 (cetakan ke-1). Novel Keajaiban Adam karya Gusti M Fabiano ini terdiri dari 9 sub bab, tebalnya 402 halaman. Semua kata dan kalimat yang mengandung tokoh dan penokohan dijadikan sebagai data. Judul yang terdapat dalam novel Keajaiban Adam karya Gusti M Fabiano adalah Sudut Nadirat, Atmosfir Diri, Isra-Miraj Adam, Polemik Horizonta, Percobaan Pembunuhan, Hijrah ke Bali, Yusuf, Agin Kedamaian, Kemelut Cinta.

Teknik pengumpulan data pada penelitian ini adalah teknik dokumentasi. Teknik pengumpulan data dengan menggunakan teknik dokumentasi, yakni peneliti mencari objek yang diteliti dengan cara membaca kalimat demi kalimat dalam novel Keajaiban Adam karya Gusti M Fabiano. Selanjutnya, penelitimenandai setiap data yang terdapat dalam novel dan dipindahkan ke dalam tabel sesuai rumusan masalah. Terakhir, peneliti menganalisis tentang tokoh dan perwatakan tokoh yang terdapat dalam novel Keajaiban Adam karya Gusti M Fabiano.

Menurut Arikunto (2006:231), "Metode dokumentasi adalah mencari data mengenai hal-hal atau variabel yang berupa catatan, transkrip, buku, surat kabar, majalah, prasasti, natulen rapat, lengger, agenda dan sebagainya". Dokumen merupakan sumber informasi yang bukan manusia (non human resources) (Satori dan Aan, 2017:146). Metode dokumentasi merupakan metode yang tidak terlalu sulit dikarenakan dokumentasi adalah metode yang dilakukan untuk menyediakan dokumen dengan menggunakan bukti yang akurat dari pencatatan sumber-sumber informasi khusus dari karangan atau tulisan dan sebagainya. Apabila terjadi kekeliruan atau kesalahan dalam pengumpulan data, sumber datanya masih tetap dan tidak ada perubahan.

Mules dan Huberman (dalam Sugiyono, 2018:246), mengwmukakan bahwa "Aktivitas dalam analisis data kualitatif dilakukan secara interaktif dan berlangsung secara terus menurus sampai tuntas, sehingga datanya sudah jenuh. Aktivitas dalam analisis data yaitu:

1. Reduksi Data (Data Reduction)

Data yang diperoleh di lapangan jumlahnya cukup banyak, umtuk itu maka perlu dicatat secara teliti dan rinci. Mereduksi data berarti merangkum, memilih hal-hal yang pokok, memfokuskan pada hal-hal yang penting dicari tema dan polanya.

2. Penyajian Data (Data Display)

Setelah data direduksi, maka langkah selanjutnya adalah mendisplaykan data. Kalau dalam penelitian kuantatif penyajian data ini dapat dilakukan dalam bentuk tabel, grafik, pie chard, pictogram, dan sejenisnya. Melalui penyajian data tersebut, maka data terorganisasikan, tersusun dalam pola hubungan, sehingga akan semakin mudah dipahami.

3. Kesimpulan (conclusion drawing/veryfication) Langkah ketiga dalam analisis data kualitatif adalah penarikan kesimpulan dan verifikasi. Kesimpulan awal yang dikemukakan masih bersifat sementara, dan akan berubah bila tidak ditemukan bukti-bukti yang kuat yang mendukung pada tahap pengumpulan data berikutnya. Tetapi apabila kesimpulan yang dikemukakan pada tahap awal, didukung oleh bukti-bukti yang valid dan konsisten saat peneliti kembali ke lapangan mengumpulkan data, maka kesimpulan yang dikemukakan merupakan kesimpulan yang kredibel (dapat dipercaya atau bias dipertanggung jawabkan).

\section{Hasil dan Pembahasan}

Dalam penelitian ini, peneliti mendeskripsikan tokoh dan penokohan yang terdapat pada novel Keajaiban Adam karya Gusti M Fabiano. Dari hasil pengamatan, peneliti menemukan 23 tokoh berperan dengan berbagai jenis penokohan yang dilukiskan oleh Gusti M Fabiano. Tokoh- tokoh tersebut terdiri dari Adam, Ibu Yusti, Pak Ustad Sobri, Tuty, Cut Putri, Pak Hasan, Pak Badri, Pak Surya, Bu Intan, Pak Baharuddin, Pak Yudhi, Prisma Sari, Aprilia, Ibu Shinta, Pak Darius, Ibu Tiri Prisma, Papa Prisma, Chistian, Ustad Mustafa, Pak geuchiek, Pak Wayan, dan Pak Arifin.

Berikut ini adalah tokoh dan penokohan yang terkandung dalam novel Keajaiban Adam karya Gusti M Fabiano.

1. Adam

Tokoh Adam merupakan tokoh utama protagonis dalam novel keajaiban Adam. Tokoh Adam memiliki penokohan yang begitu sempurna seperti religius, sabar, mandiri, suka menolong dan berbagai karakter baik lainnya. Tokoh Adam juga yang sederhana dan statis. Hal ini dikarenakan karakternya sebagai tokoh protagonis dari awal cerita tidak berubah dan karakter protaginis tersebut terus bertahan hingga akhir cerita.Penokohan dari sosok Adam digambarkan oleh Fabiano dengan beberapa karakter berikut:

a. Religius 


\section{Juni 2020}

Sifat yang paling dominan muncul pada tokoh Adam adalah religius. Sifat religius tersebut tergambar dalam penggalan teks berikut:

Setelah doa dari solat magrib
berjamaah di mushalla Nurul
Iman, Adam berjalan menepi,
menyudutkan diri ke tembok
mushallah untuk membaca
beberapa ayat suci Al-
Quran.Tapi... "Bi...bi...bbb...iii...
iiss...iss..” lidahnya seperti kaku
untuk mengucapkan lafazh
bismillah. Dia mengulangi sekuat
tenaga. (Fabiano, 2012:7)

Dari penggalan teks di atas, dapat disimpulkan bahwa sosok Adam sosok yang religius. Hal ini terlihat dari kalimat Setelah doa dari solat magrib berjamaah di mushalla Nurul Iman, kalimat ini menunjukkan bahwa tokoh Adam digambarkan sebagai sosok yang tidak lepas dari kegiatan peribadatan.

\section{b. Tak putus asa}

Sifat lainnya yang dimunculkan oleh penulis novel pada tokoh utama Adam adalah tidak mudah putus asa. Gambaran dari sifatnya tersebut dapat dilihat dari penggalan teks berikut ini:

Dia menjulurkan lidah. Jempol,
telunjuk dan jari tengah
mengkantum alat pengecap dan
perasa itu. Dengan menarik nafas
panjang, keluar dari mushalla
dan berlari ke arah barat menuju
rumah. Meski di masa berlari ia
teringat dengan hutan dan lidah
yang kaku tanpa sebab, selalu
membuat kesal bila ingin
mengawali dalam mengaji.
Namun ia tetap tak putus asa.

(Fabiano, 2012:8)

Dari penggalan teks di atas, dapat dilihat bahwa sosok adam adalah sosok yang tidak mudah putus asa. Sejak lahir ia tidak bisa mengucapkan kalimat bismillah, dan ia terus saja berusaha untuk mengucapkannya walaupun usahanya tersebut selalu gagal. Karakter lainnya yang tergambar dari tokoh adam adalah sabar. Sifat sabar tersebut dapat dilihat dari penggalan teks berikut ini:

\section{c. Sabar}

Adam menarik nafas melihat ketiga adik kelasnya meninggalkan tempat itu, ia masih bisa mendengar bisikkan negatif salah satu teman Tuty yang melarang jangan terlalu dekat dengannya. Adam menggeleng meresapi hidup dalam bayangan suatu nadirat yang sulit di pahami. (Fabiano, 2012:21)
Dari penggalan teks di atas, tertulis tentang gambaran dari sifat Adam ketika dihina di sekolahnya. Meskipun kebanyakan siswa mencela dan memusuhinya, namun ia tidak pernah membalas perbuatan orang tersebut. Ia hanya membiarkannya saja dan hanya merenungi nasib yang menimpanya.

\section{Cut Putri}

Cut Putri adalah tokoh utama protagonis, ia berperan sebagai tokoh yang baik dalam novel Keajaiban Adam. Cut Putri adalah tokoh bulat dan berkembang. Pada awalnya ia bersifat baik terhadap semua orang, namun, sifatnya berubah terhadap tokoh Prisma dikarenakan kedekatannya dengan tokoh Adam. Cut Putri juga merupakan tokoh netral, ia eksis dengan perannya sendiri sebagai pasangan Adam saat ia tinggal di Banda Aceh. Ia adalah sosok perempuan yang mempunyai hubungan dekat dengan Adam saat ia tiba di Banda Aceh. Gambaran dari sosok Cut Putri dalam kehidupan Adam yang dikisahkan oleh Fabiano dapat dilihat dalam penggalan teks berikut ini:

a. Teguh Pendirian

Penokohan yang digambarkan pada tokoh Cut Putri adalah Teguh Pendirian. Karakter teguh pendirian tersebut tergambar pada penggalan cerita di bawah ini:

"Tidak mungkin Adam melakukan seperti itu, Putri sangat kenal Adam!! Dia tidak mungkin berbuat kotor seperti itu. Selama bersama Putri Adam tak pernah berani berbuat senonoh." Papar Cut Putri membela Adam (Fabiano, 2012:43)

Pada penggalan teks di atas, tampak bahwa tokoh Cut Putri sangat teguh pada pendiriannya. Dia tidak percaya bahwa Adam telah memperkosa $\mathrm{Bu}$ Intan walaupun semua bukti memberatkan Adam dan semua orang telah menuduhnya.

b. Patuh

Penokohan lainnya yang muncul dari tokoh Cut Putri adalah patuh. Sebagaimana yang tertulis dalam penggalan cerita di bawah ini:

"Mungkin nanti Adam pulang sendiri, kita tunggu saja.” Kata terakhir Pak Hasan. Dengan lesu Cut Putri menuruti saran orang tua di sebelahnya. (Fabiano, 2012: 46)

Pada teks di atas, tertulis bahwa Cut Putri adalah sosok yang patuh. Dia mendengarkan saran dari Pak Hasan untuk menunggu Adam pulang.

c. Kekanakan 


\section{Juni 2020}

Penokohan lainnya yang digambarkan oleh Fabiano pada tokoh Cut Putri adalah kekanakkanakan. Karakter kekanak-kanakan tersebut dapat dilihat dalam penggalan cerita di bawah ini:

Di kampus biasa Cut Putri energik, lincah bersahutan dan terkadang cekikikan sesama teman kampus dan bila lagi iseng menggoda teman yang lain, mahasiswi yang satu ini sering bertingkah kekanakan. Sekarang ada yang beda, terasa menjadi hambar. (Fabiano, 2012: 50)

Teks di atas menggambarkan sifat kekanak-kanakan dari tokoh Cut Putri. Penegasan dari sifat kekanak-kanakan tersebut terdapat pada kalimat dan bila lagi iseng menggoda teman yang lain, mahasiswi yang satu ini sering bertingkah kekanakan. Tokoh Cut Putri adalah sosok yang ceria dan suka bercanda seperti anak-anak. Oleh karena itu, ia disebut berkarakter kekanak-kanakan.

\section{Ibu Yusti}

Selain tokoh Adam, penulis juga menampilkan tokoh utama protagonis lainnya dalam novel Keajaiban Adam. Ibu Yusti adalah ibu kandung Adam yang tinggal di kampung. Ia merupakan tokoh utama protagonis yang kerap kali muncul dalam cerita dengan berbagai penokohan yang baik. Tokoh Ibu Yusti juga merupakan tokoh yang sederhana dan statis. Dari awal hingga akhir cerita, Fabiano menggambarkan tokoh Ibu Yusti sebagai karakter Ibu yang baik. Tokoh Ibu Yusti juga merupakan tokoh netral, ia berperan untuk membentuk karakter dirinya sendiri di dalam cerita. Dia adalah sosok yang melahirkan Adam dan membesarkannya tanpa sosok Ayah. Gambaran tentang tokoh Ibu Yusti yang dilukiskan oleh Fabiano dapat dilihat dalam beberapa teks berikut ini:

a. Tabah

Sikap yang paling menonjol yang muncul pada tokoh Ibu Yusti adalah tabah. Gambaran sifat tabah dari tokoh Ibu Yusti dilukiskan dalam penggalan cerita berikut ini:

Sosok wanita telah lama di tinggal suaminya, menabahkan hati bersama seorang putra yang tak mengetahui siapa Bapak yang sebenarnya. Lambaian tangan penuh kasih, kibasan angin menjulurkan sampai ke sulfi, sulur-sulur armbut masih terawat belum tampak uban dalam helaian rambutnya. (Fabiano, 2012:2)

Dalam teks di atas, terdapat kalimat Sosok wanita telah lama di tinggal suaminya, menabahkan hati bersama seorang putra yang tak mengetahui siapa Bapak yang sebenarnya menunjukkan ketabahan dari sosok Ibu Yusti, walaupun sudah lama ditinggal mati suaminya, Ibu Yusti tetap hidup menjanda dan membesarkan putranya tersebut seorang diri.

\section{b. Religius}

Penokohan lainnya yang digambarkan oleh Fabiano pada sosok Ibu Yusti adalah religius, sebagaimana yang dituliskan oleh Fabiano dalam penggalan teks berikut ini:

Sampai di rumah,. Tekat yang kuat seakan luluh, batu yang keras menjadi lunak, keinginan menggelora menghujam banyak pertanyaan kepada sang Ibu menjadi punah. Bahasa diam, bahasa bisu, melihat senyuman seorang Ibu, Nampak dengan wajah meranum sejuta ketabahan dlam hidup degan masih memakai kerudung seusai shalat fardhunya. (Fabiano, 2012:9)

Dalam paragraf di atas, terdapat kalimat Nampak dengan wajah meranum sejuta ketabahan dlam hidup degan masih memakai kerudung seusai shalat fardhunya. Kalimat ini menggambarkan bahwa tokoh Ibu Yusti adalah sosok yang religius. Dalam kalimat tersebut tertulis bahwa ia masih memakai kerudung seusai melaksanakan ibadah shalat fardhu.

\section{c. Khawatir}

Penokohan lainnya yang dicerminkan pada tokoh Ibu Yusti adalah rasa khawatir. Sikap khawatir tersebut digambarkan oleh Fabiano dalam penggalan cerita berikut ini:
"Saya cuma khawatir, nanti
dia bangga dengan apa yang telah terjadi, saya takut!! Nanti dia menyimpang dari ajaran Rasullullah". Keluh tebak Ibu Yus. (Fabiano, 2012: 113)

Pada teks di atas, sifat khawatir dari tokoh Ibu Yusti terdapat pada kalimat Saya cuma khawatir, nanti dia bangga dengan apa yang telah terjadi, saya takut!.Pada kalimat tersebut, mencerminkan bahwa Ibu Yusti sangat cemas pada keadaan putranya. Ibu Yusti takut bahwa putranya itu terbawa akan suasana keajaiban yang selalu Adam alami sejak lahir dan takut apabila Adam tersesat dan menyimpang dari ajaran Islam nantinya.

\section{Pak Ustad Sobri}

Tokoh lainnya yang sangat berperan dalam kehidupan sosok utama Adam adalah ustad Sabri, beliau adalah seorang pemuka Agama yang sudah dekat dengan Adam dan keluarganya semenjak Adam masih kecil. Tokoh Ustad Sobri merupakan 


\section{Volume 3 Nomor 1}

\section{Juni 2020}

tokoh tambahan protagonis. Tokoh ini juga sederhana dan statis, tokoh Ustad Sobri hanya memerankan satu tipe karakter di dalam novel Keajaiban Adam. Tokoh ini juga merupakan tokoh tipikal, kehadirannya hanya untuk melengkapi dan mendukung peran lain dalam cerita. Gambaran tentang sosok ustad Sobri dalam novel Keajaiban Adam dapat dilihat dalam penggalan-penggalan teks berikut ini:

a. Motivator

Penokohan yang digambarkan oleh Fabiano pada tokoh pak Ustad Sobri adalah motivator. Karakter motivator tersebut tercermin dalam penggalan cerita berikut ini;

“Jangan putus asa. Maaf...Nak Adam, sering ke hutan, pernah berjumpa Bapakmu? Mungkin dia sendiri yang bisa mengobati lidahmu??" Pak Ustad Masih meyakini akan proses pemulihan lidah anak didikannya itu.

(Fabiano, 2012:25)

Dari penggalan cerita di atas, terlihat bahwa tokoh pak Ustad Sobri merupakan sosok motivator. Ia selalu memberi dukungan kepada Adam setiap mengalami masalah di kampung. Pak Ustad Sobri selalu memberikan nasihat-nasihat yang bijaksana kepada Adam mengenai masalah yang sedang dihadapinya itu.

b. Peduli

Penokohan lainnya yang digambarakan Fabiano pada tokoh ustad Sobri adalah sosok yang sangat peduli. Sebagaimana yang tertulis dalam penggalan teks di bawah ini:

Ustadz Sobri terus membolakbalikkan Koran serambi Ummah yang biasa melemparkan wacana Islami kepada pembacanya, teras balkon Rumah yang setiap pagi menjadi tempat penyambung waktu menunggu siang menerima pancaran keresahan sang penghuni, matanya terus membelalaki Koran di tangan, di bacanya berulang kali memastikan kabar yang sedang hangat pada saat ini. Pikirannya melayang pada sosok anak muda, beberapa hitungan jantungnya sempat berdebar-debar merisaukan anak didiknya yang telah lama meninggalkan kampung (Fabiano, 2012:111)

Dari penggalan cerita di atas, dapat dilihat bahwa ustad sobri adalah sosok yang sangat peduli pada sesama. Seperti yang tertulis dalam kalimat Pikirannya melayang pada sosok anak muda, beberapa hitungan jantungnya sempat berdebardebar merisaukan anak didiknya yang telah lama meninggalkan kampung. Pada kalimat ini, tampak jelas bahwa ustad Sobri sangat peduli pada tokoh Adam, beliau dengan sengaja mencari tahu kabar Adam melalui surat kabar. Ustad Sobri sangat peduli pada tokoh Adam meskipun mereka bukanlah keluarga.

\section{c. Humoris}

Penokohan lainnya yang tergambar pada tokoh ustad Sobri adalah humoris. Sifat humoris dari tokoh ustad Sobri, digambarkan oleh Fabiano pada penggalan cerita di bawah ini:

"Siapa tau saja anak dan Ibu bisa terbang ke sana dengan sekejap." "Hahaha..." "Pak Ustadz ini ada-ada saja." Senyum geleng Ibu Yus." "Maaf Bu! Saya becanda, siapa sih sebagai Muslim yang tidak ingin pergi ke Makkah.(Fabiano, 2012:114)

Pada teks di atas, tertulis bahwa ustad Sobri sedang bercanda dengan Ibu Yusti. Di tengah ketegangan suasana karena keajaiban Adam yang bisa terbang hingga ke Mekkah, Ustad Sobri pun menjadikan kejadian itu sebagai bahan candaan kepada Ibu Yusti, sebagaimana yang tertulis pada kalimat Maaf Bu! Saya becanda, siapa sih sebagai Muslim yang tidak ingin pergi ke Makkah.

\section{Tuty}

Tokoh lainnya yang digambarkan dalam novel Keajaiaban Adam adalah sosok Tuty. Dia adalah teman Adam di kampung sejak kecil. Tokoh Tuty merupakan tokoh protagonis tambahan yang mempunyai karakter baik di dalam cerita. Tuty juga merupakan tokoh sederhana dan statis, ia hanya memainkan satu tipe karakter dalam novel Keajaiban Adam, dan karakter tersebut tidak berubah hingga akhir cerita. Tuty juga merupakan tokoh netral, ia memiliki peran tersendiri sebagai pasangan tokoh Adam saat ia tinggal di kampung. Tuty adalah anak dari Ustad Sobri. Sosok Tuti merupakan sosok yang sangat membela Adam di kalangan teman-temannya di sekolah dan di kampong. Penulis menggambarkan sosok Tuti dalam beberapa karakter berikut ini:

a. Teguh Pendirian

Penokohan pertama yang digambarkan oleh pengarang pada tokoh Tuty adalah teguh pendirian. Sebagaimana yang tertulis pada penggalan teks di bawah ini:
"Ya, masih dong. Omongan itu benar atau tidak ?! Bagi Tuty Kak Adam dan Ibu Yus adalah orang baik, Tuty dan keluarga kan sudah mengenal banget kalian." (Fabiano, 2012: 20) 
Juni 2020

Pada penggalan teks di atas, tergambar karakter Tuty yang teguh pendirian. Walaupun semua sudah berpandangan negatif terhadap sosok Adam, namun Tuty tidak terbawa suasana. Ia tetap percaya bahwa Adam adalah orang baik, meskipun semua orang menuduh Adam sebagai makhluk halus, orang aneh, keturunan setan dan lain sebagainya.

\section{b. Keras Kepala}

Penokohan lainnya yang digambarkan oleh Fabiano pada tokoh Tuty adalah sosok yang keras kepala, sebagaimana yang tercermin dalam penggalan teks berikut ini:

"Tapi, Tuty tetap tidak mau omong dengannya. " Keras kehendak Tuty Nampak ketidak dewasaannya. Geleng Adam sebentar. (Fabiano, 2012: 21)

Pada teks tersebut, tokoh Tuty digambarkan sebagai sosok yang keras kepala. Tuty tidak mau mendengarkan nasihat Adam, walaupun Adam memberikan saran yang lebih baik untuknya.

\section{c. Dermawan}

Penokohan lainnya yang tercermin pada tokoh Tuty adalah dermawan, sifat dermawan tersebut tergambar pada teks di bawah ini:

Ibu Yus menatap dari kejauhan langit yang sudah berubah menjadi gelap. Tuty datang membawa rantangan di tangan, semenjak Adam pergi Tuty jadi setiap hari ke rumah Adam menemani Ibu Yus dan Nini. Ibu Yus jadi iba melihatnya, ada perasaan kasihan bila dia menanyakan kabar Adam. (Fabiano, 2012: 87)

Pada teks di atas, tercermin karakter dermawan pada tokoh Tuty, sebagaimana kalimat Tuty datang membawa rantangan di tangan, semenjak Adam pergi Tuty jadi setiap hari ke rumah Adam menemani Ibu Yus dan Nini. Tokoh Tuty suka berbagi pada sesama, khususnya pada Ibu Yus, Ibunya Adam. Tuty suka memberi dan membantu Ibu Yusti yang hidup serba kekurangan tanpa sosok suami.

\section{Simpulan dan Saran}

Berdasarkan hasil analisis, peneliti menemukan 23 tokoh yang berperan dengan berbagai jenis penokohan yang dilukiskan oleh Gusti M Fabiano. Tokoh- tokoh tersebut terdiri dari Adam, Ibu Yusti, Pak Ustad Sobri, Tuty, Cut Putri, Pak Hasan, Pak Badri, Pak Surya, Bu Intan, Pak Baharuddin, Pak Yudhi, Prisma Sari, Aprilia, Ibu Shinta, Pak Darius, Ibu Tiri Prisma, Papa Prisma, Christian, Ustad Mustafa, Pak geuchiek, Pak Wayan, Pak Arifin, dan Nini. Ada beberapa tokoh yang dikategorikan lebih dari satu perannya. Penokohan dalam novel ini dideskripsikan melalui watak yang berbeda-beda setiap tokohnya, diantanya: religius, tidak putus asa, sabar, mandiri, suka menolong, penuh keajaiban, jujur, bersyukur, rendah diri, mengesankan, motivator, pandai menghibur, tau diri, tidak mau dikasihani, penyayang dan bijaksana, humoris, peduli, Teguh pendirian, keras kepala, dermawan, menenangkan, suka berprasangka, Putus Asa dan berjiwa besar, kritis, tempramen, Tidak sopan, pembohong, takut dan menyesal, Tegas, penasaran, centil, angkuh, cemburu, dan tidak bertanggung jawab.

Dalam penelitian ini, penulis berharap kepada seluruh pembaca, khususnya mahasiswa jurusan Bahasa dan Sastra Indonesia untuk lebih memperdalam pengetahuannya terhadap cara-cara menggambarkan tokoh dan penokohan pada karya sastra novel. Penulis berharap kepada pengarang novel Gusti M Fabiano untuk menampilkan tokoh pada novel dengan penokohan yang lebih menarik lagi, khususnya pada tokoh utama novel. Tokoh Adam dalam novel Keajaiban Adam terkesan begitu sempurna tanpa adanya karakter negatif sedikitpun dan hal ini sulit dijumpai pada karakter manusia pada umumnya.

\section{Daftar Rujukan}

Aminuddin. 2015. Pengantar Apresiasi Karya Sastra. Bandung: Sinar Baru Algensindo.

Arikunto, Suharmisi. 2006. Prosedur Penelitian Suatu Pendekatan Praktik. Jakarta: PT. Renika Cipta.

Fanani, Burhan. 2016. Mengayakan Kalimat dan Imajinasi. Yogyakarta: Araska.

Kemal, Isthifa. 2014. Analisis Tokoh Dan Penokohan Dalam Hikayat Muda Balia Karya Teuku Abdullah Dan M. Nasir. Vol.2. No.2.

Madina, La Ode. 2018. Analisis Penokohan Pada Novel "Tentang Kamu" Karya Tere Liye. Vol.1. No.1.

Masruroh, Ainun. 2017. Rambu-Rambu Menulis Cerpen. Yogyakarta: Pusat Kajian Bahasa.

Minderop, Albertine. 2013. Metode Karakterisasi Telaah Fiksi. Jakarta: Yayasan Pustaka Obor Indonesia.

Nurgiyantoro, Burhan. 2013. Teori Pengkajian Fiksi. Yogyakarta: Gajah Mada University Press.

Priyatni, Endah Tri. 2012. Membaca Sastra dengan Ancangan Literasi Kritis. Jakarta: PT. Bumi Aksara. 
Jurnal Samudra Bahasa

Volume 3 Nomor 1

Juni 2020

Ratna, Nyoman kutha. 2017. Teori, Metode dan

Teknik Penelitian Sastra. Yogyakarta: Pustaka Belajar.

Riani, Ucha, dkk. 2016. Analisis Tokoh dan Penokohan dalam Novel Sepatu Dahlan Karya Khrisna Pabichara. Vol.1. No.4. Jurnal Ilmiah Mahasiswa Jurusan PBSI.

Satori, Djam'an dan Aan Komariah. 2017. Metodologi Penelitian Kualitatif. Bandung: Alfabeta.

Seanal, Muhammad. 2016. Perbandingan karakter tokoh dalam novel jangan bercerai bunda karya asma nadia dengan putri kecilku dan astrocytoma karya dr. elia barasila, M.A.R.S dan dr. sanny Santana Sp. OG. Vol. 16. No. 1. Jurnal Humanika.

Semi, M Atar. 2012. Metode Penelitian Sastra. Bandung: Angkasa Bandung.

Teeuw, A. 2015. Sastra dan Ilmu Sastra. Bandung: PT. Dunia Pustaka Jaya.

Wahyuningtyas, Sri dan Wijaya Heru Santosa. 2011. Sastra: Teori dan Implementasi. Surakarta: Yuma Pustaka.

Yoanita, Ika. 2011. Kepribadian Tokoh Utama "Ketika Cinta Bertasbih" Episode 1 Karya Habiburrahman El Shirazy Berdasarkan Teori Golden Allport. Vol.12 No.2. Jurnal Artikulasi 